\title{
36 Minimising the hydrological impact of forest harvesting in Malaysia's rainforests
}

\author{
H. C. Thang \\ Forestry Department, Peninsular Malaysia \\ N. A. Chappell \\ Lancaster University, UK
}

\section{INTRODUCTION}

Malaysia has a long experience of forestry management, with the Forestry Department of Peninsular Malaysia being established in 1901. Measures to improve the prospects of natural forest regeneration after the first cut were first applied in 1910, improved in 1927, and again in 1950 with the introduction of the Malayan Uniform System (MUS) ${ }^{1 *}$ and latterly with the application of the Selective Management System (SMS)* since the late 1970s (Thang, 1987; Jusoff and Mustafa, 1996; Dawkins and Philip, 1998, p. 154). The guidelines associated with these management systems aim to enhance regeneration in part by limiting collateral damage to trees remaining after the cut. This has the indirect effect of: (a) restricting damage to natural canopies and hence reducing changes to transpiration and wet-canopy evaporation (Asdak, et al., 1998, Chappell, et al., 2001, van Dam, 2001), and (b) requiring more careful skidding* or yarding* systems, thereby reducing ground damage (Pinard et al., 2000) and hence soil erosion (Douglas et al., 1993; Chappell et al., 1999).

Methods of commercial forestry in Malaysia developed greatly from the mid-50s onwards, with Malaysian companies now expanding their operations to other tropical countries. Inevitably, with the advancement of forestry technology has come a greater degree of mechanisation, and the potential for greater impact on the physical and biological environment (Wyatt-Smith et al., 1964). Greater mechanisation within agriculture or urban development has magnified the detrimental impacts on the environment, as well as magnified the positive social effects (Pereira, 1973; Trewin et al., 1998), so there should be no reason to believe that the intensified terrain and vegetation manipulation associated with more mechanised forestry should be immune from such impacts. Traditionally, Malaysian timber was cut and then hauled manually ('kuda-kuda') to landing areas* where it was then transported by river or rail (Sabah Forestry Department, 1989; Jusoff and Mustafa, 1996). Compared with the use of tracked vehicles ('skidders') and haulage lorries, such extraction is slow and costly, and would not give the state or nation the revenue to develop schools, hospitals and other social necessities (FAO, 1997; Sabah Forestry Department, 1989). In 2001, the revenue generated from the export of timber and timber products from Malaysia amounted to US\$ 3,770 million.

As forestry methods changed, guidelines have had to be modified to reflect the changing effects on forest regeneration (Dawkins and Philip, 1998). With the intensification of the operations, concerns have extended beyond the need to sustain timber production to consider off-site hydrological impacts such as turbid water supplies (Mohamed, 1987) and enhanced flood risk from increased channel sedimentation (Sheffield et al., 1995). As an acknowledgement of this, state forestry policies were developed to mitigate impacts other than those impinging directly on timber production, including those related to the soil and water environment (Wyatt-Smith et al., 1964).

During the 1990s the International Tropical Timber Organisation (ITTO), the Forest Stewardship Council (FSC) and several other organisations, notably Rainforest Alliance, Scientific Certification Systems (SCS) and Société Générale de Surveillance S.A. (SGS), developed guidelines allowing assessors to judge the sustainability of Natural Forest* management. In response, key organisations in Malaysia, notably the Forestry Department Headquarters (Peninsular Malaysia), the State Forestry Departments, the Forest Research Institute of Malaysia (FRIM), the Malaysian Timber Council (MTC) and the Malaysian Timber Certification Council (MTCC), restructured the existing guidelines to make them compatible with the ITTO criteria* and indicators*

1 Technical words with asterisks are detailed in Appendix 36.1 at the end of the chapter. 
of sustainable forestry (ITTO, 1999). These are formally known as the 'Malaysian Criteria, Indicators, Activities and Standards of Performance for Forest Management Certification' or 'MC\&I' (Thang, 1996). Further revisions of the MC\&I have taken place (MTCC, 2001) in response to the major revision of the ITTO guidelines in 1998/9 (ITTO, 1999), and remain ongoing with, for example, the recent adoption of a set of 'Malaysian Criteria and Indicators for Forest Management Certification' in October 2002 which is technically compatible with the 'FSC Principles and Criteria' (Forest Stewardship Council, 2000; Thang, 2003).

Furthermore, Malaysia has been at the forefront of research on the hydrological, ecological and botanical impacts of forestry operations at field stations throughout Malaysia. These include Pasoh (Leigh, 1982; Condit et al., 1999), Bukit Berembun (Abdul Rahim and Yusop, 1994; Abdul Rahim et al., 1997), Bukit Tarek (Yusop, 1996), Hulu Langat and Sg. Lalang Forest Reserves (Lai, 1992) in the States of Peninsular Malaysia, the MFMA area of central Sarawak State (Holmes, 1995; Chua, 1996, 2001), and Sipitang (Malmer and Grip, 1994), Deramakot (Huth and Ditzer, 2001), and Ulu Segama / Danum Valley (Douglas et al., 1993, 1995, 1999; van der Plas and Bruijnzeel, 1993; Pinard et al., 1995, Chappell et al., 1999) in Sabah State. Findings from this ongoing research are furthering the developing forestry guidelines.

\section{THE MC\&I SOIL AND WATER CRITERION OF SUSTAINABLE FORESTRY MANAGEMENT}

ITTO (1999) defined seven criteria of sustainable forestry applicable at both the national and Forest Management Unit (FMU) levels. An FMU is a clearly defined forest area, managed to a set of explicit objectives and according to a long-term management plan (ITTO, 1999). Within Malaysia, the FMU can be one of the forest blocks under the management of a District Forest Officer, e.g. 'FMU 19' in Sabah State which consists of the 55,083 ha Deramakot Forest Reserve (FR) and the 57,240 ha SegaliodLokan FR, or it could be a whole state, e.g. the Selangor FMU which includes 234,644 ha of Permanent Forest Estate (PFE). PFE is land, whether public or private, secured by law and kept under permanent forest cover (ITTO, 1999, MTCC, 2001). Within Malaysia, 14.45 million ha (or $72 \%$ of all forest) is designated as PFE (under the National Forestry Policy, 1978, revised 1992). Some 3.81 million ha (or 26\%) of the PFE exists as large blocks of 'Protection Forest', leaving 10.64 million ha (or 75\%) of PFE as 'Production Forest' (Table 36.1). Forest Reserves gazetted using the National Foresty Act (1984, Section 10:1) as 'PFE Protection Forest' comprise the formal classes of Soil Protection Forest, Soil
Table 36.1. Permanent Forest Estate (PFE) within Malaysia (million ha in 2001)

\begin{tabular}{llcc}
\hline \hline Region & $\begin{array}{l}\text { Protection } \\
\text { Forest }\end{array}$ & $\begin{array}{l}\text { Production } \\
\text { Forest }\end{array}$ & $\begin{array}{l}\text { Total land } \\
\text { under PFE }\end{array}$ \\
\hline Peninsular Malaysia & 1.90 & 2.95 & 4.85 \\
Sabah & 0.91 & 2.69 & 3.60 \\
Sarawak & 1.00 & 5.00 & 6.00 \\
All Malaysia & 3.81 & 10.64 & 14.45 \\
\hline \hline
\end{tabular}

Reclamation Forest, Flood Control Forest, Water Catchment Forest, Forest Sanctuary for Wildlife, Virgin Jungle Reserved Forest, Amenity Forest, Education Forest and Research Forest. Commercial felling of trees is prohibited within all areas gazetted as PFE Protection Forest. Commercial forestry is undertaken with areas gazetted as PFE Production Forest (also called Class II Forest Reserve in Sabah State), though harvesting may be prohibited in some parts of this PFE Production Forest (e.g. stream buffer zones*, local areas $>1000 \mathrm{~m}$ a.s.l.). The respective forestry departments aim for all forestry with the PFE Production Forest to be undertaken sustainably (Thang, 2003), though the forestry operations within a significant proportion of this forest have yet to be certified as 'sustainably managed' by third party, international assessors.

Except for a few thousand hectares of plantation forests, the PFE is Natural Forest*, which is forest land composed of indigenous trees, not planted by man (ITTO, 1999). Certification of sustainable management practices within Malaysia's Natural Forest (or rainforest) is currently undertaken at the scale of the FMU. For this certification* process the Malaysian Timber Certification Council and the associated independent, third parties (e.g. SGS (Malaysia) Sdn. Bhd.) are currently using six criteria of sustainability. These are: Criterion 1: Enabling conditions for sustainable forest management, Criterion 2: Forest resources security, Criterion 3: Flow of forest produce, Criterion 4: Biological diversity, Criterion 5: Soil and water, Criterion 6: Economic, social and cultural aspects (MTCC, 2001; SGS, 2002). These criteria names are as those within the most recent ITTO guidelines (ITTO, 1999), except that ITTO criterion 'Forest ecosystem health and condition' (which requires details of any natural or anthropogenic damage to the PFE) has been omitted because of perceived duplication. Some forest reserves in Malaysia have been certified according to slightly different criteria, e.g. the Deramakot FR certificate issued in 1997 (SGS, 1997), was based on compliance with the pre-1999 MC\&I (Thang, 1996) and the FSC Principles and Criteria (Forest Stewardship Council, 2000), and the certificate for the Perak Integrated Timber Complex (ITC) concession of the Temengor FR issued in 2002 (SCS, 2002), was based on compliance with FSC Principles and Criteria. 


\section{Indicators of the MC\&I Soil and Water Criterion}

The criterion that explicitly addresses practices that protect the hydrological environment is the MC\&I Criterion 5: Soil and Water. Of the nine ITTO-defined indicators, six are currently utilised for MC\&I certification (MTCC, 2001; Thang, 2002), viz.

(5.1) Extent and percentage of total forest area managed primarily for the protection of soil and water.

(5.2) Extent and percentage of area to be harvested which has been defined as environmentally sensitive (e.g. very steep or erodible) and protected before harvesting.

(5.3) Percentage of length of edges of watercourses, water bodies, mangroves and other wetlands protected by adequate buffer strips.

(5.4) Existence and implementation of procedures to identify and demarcate sensitive areas for the protection of soil and water.

(5.5) Availability and implementation of guidelines for forest road lay-out, including drainage requirements and conservation of buffer strips along streams and rivers, and

(5.6) Availability and implementation of harvesting procedures: (a) to protect the soil from compaction by harvesting machinery, and (b) to protect the soil from erosion during harvesting operations (MTCC, 2001).

\section{Performance standards associated with the indictors of the MC\&I Soil and Water Criterion}

Associated with each of the indicators are a series of activities* and a series of very specific standards of performance or SOPs*. Within Malaysia, the same SOPs are applied to those states that form the Forestry Department Peninsular Malaysia (i.e. Perlis, Kedah, Penang, Kelantan, Perak, Terengganu, Pahang, Selangor, Negeri Sembilan / Melaka and Johore), though different SOPs are currently applied within the East Malaysian states of Sabah and Sarawak. This chapter will focus primarily on the SOPs used within Peninsular Malaysia, as these are currently the most clearly defined (MTCC, 2001). The SOPs associated with the six indicators listed above are discussed briefly.

\section{(5.1) EXTENT AND PERCENTAGE OF TOTAL FOREST AREA MANAGED PRIMARILY FOR THE PROTECTION OF SOIL AND WATER}

Within Peninsular Malaysia, the SOP for this indicator comprises the extent of PFE Protection Forest gazetted as 'Soil Protection Forest' and 'Water Catchment Forest', and the extent of PFE Production Forest that is excluded from logging because it is more than $1000 \mathrm{~m}$ a.s.l., within areas of $>40^{\circ}$ slope, or water catchment areas not formally gazetted under the National Forestry
Act (1984). The SOP requires that felling is prohibited within all of these areas (MTCC, 2001; SGS, 2002)

(5.2) EXTENT AND PERCENTAGE OF AREA TO BE HARVESTED WHICH HAS BEEN DEFINED AS ENVIRONMENTALLY SENSITIVE (E.G. VERY STEEP OR ERODIBLE) AND PROTECTED BEFORE HARVESTING

The statistics under this indicator involve some overlap with those under indicator 5.1. Within Peninsular Malaysia these SOPs require that: (a) areas in the PFE Production Forest with an elevation above 1,000 $\mathrm{m}$ cannot be felled, (b) areas in the PFE Production Forest with an elevation less than 1,000 m but having slopes generally greater than or equal to $40^{\circ}$ cannot be felled, (c) trees equal to and those above cutting limits for environmentally sensitive spots within the PFE Production Forest are marked and protected, and (d) areas in the PFE Protection Forest are not felled.

\section{(5.3) PERCENTAGE OF LENGTH OF EDGES OF WATERCOURSES, WATER BODIES, MANGROVES AND OTHER WETLANDS PROTECTED BY ADEQUATE BUFFER STRIPS}

The three principal forest types classified within current Malaysian FMU forest certification documents (e.g. SGS, 2002) are 'Inland / Dipterocarp Forest', 'Peat Swamp Forest' and 'Mangrove Forest'. Within Peninsular Malaysia these SOPs require that: (a) buffer strips along permanent watercourses (called Stream Buffer Zones, or SBZs*) in Inland / Dipterocarp Forest and Peat Swamp Forest of at least $5 \mathrm{~m}$ wide on either side of the watercourse, (b) buffer strips of permanent watercourses in Mangrove Forest of at least $3 \mathrm{~m}$ wide on either side of the watercourse, and (c) buffer strips of at least $50 \mathrm{~m}$ on the seaward side of Mangrove Forest be protected from felling of trees.

\section{(5.4) EXISTENCE AND IMPLEMENTATION OF PROCEDURES TO IDENTIFY AND DEMARCATE SENSITIVE AREAS FOR THE PROTECTION OF SOIL AND WATER}

Within Peninsular Malaysia, the SOPs under this indicator are exactly the same as those under indicator 5.2. In some contrast, within Sabah the SOPs under this indicator are not simply listed (MTCC, 2001) but are stated as being contained within the documents: (a) Handbook on Forest Management, (b) Guideline on Forest Management Planning, (c) Forest Management Plan, (d) Annual Work Plan, (e) Comprehensive Harvesting Plan (e.g. Sabah Forestry Department, 1998a), (f) technical specifications for reduced-impact logging (RIL)* given in the Schedule F of the long-term Sustainable Forest Management License Agreement (SFMLA) for each FMU, (g) RIL Operation Guidebook 
Specifically for Tracked Skidder Use (Sabah Forestry Department, 1998b), (h) Cable Logging Techniques, (i) Reference Manual for Timber Harvesting Operations in Commercial Class II Forest Reserves in Sabah, and (j) the report on the measures undertaken to implement these procedures (MTCC, 2001).

\section{(5.5) AVAILABILITY AND IMPLEMENTATION OF GUIDELINES FOR FOREST ROAD LAY-OUT, INCLUDING DRAINAGE REQUIREMENTS AND CONSERVATION OF BUFFER STRIPS ALONG STREAMS AND RIVERS}

Within Malaysia, forest roads are defined as main roads, secondary roads, feeder roads and skid trails (Forestry Department Peninsular Malaysia, 1999). Particular consideration is given to the construction of: (1) feeder roads* which are the temporary roads used to transport timber by lorry out of an annual coupe*, and (2) skid trails* which are the routes made by skidders and tractors to transport timber from the stump to the log landing areas*. Within Peninsular Malaysia the SOPs required under indicator 5.5 are: (a) density of feeder roads of less than or equal to $40 \mathrm{~m} / \mathrm{ha}$, (b) density of skid trails of less than or equal to $300 \mathrm{~m} / \mathrm{ha}$, (c) right of way (corridor width) for feeder roads less than or equal to $15 \mathrm{~m}$, (d) gradient of feeder roads of less than or equal to $20 \%$, but will follow natural benches and topographic features when using existing roads or when newly specified by the Forest Department's (FD) Forest Engineer, (e) road camber (i.e. surface curvature) of feeder roads of at least $5 \%$, (f) cross-fall (i.e., average transverse slope) for feeder roads of at least $3 \%,(\mathrm{~g})$ carriageway of feeder roads (single lane) with width of at least $4 \mathrm{~m}$, except at corners and lay-bys, (h) construction of $\mathrm{V}$-shaped, earth side-drains along feeder roads, (i) adequate culverts (made from hollow logs, concrete, metal or High Density Polyethylene) located at stream or river crossings, where required or as specified by the FD Forest Engineer, (j) bridges (made from timber, concrete box culvert, or steel) of at least $3.5 \mathrm{~m}$ in width at stream or river crossings, where required, (k) silt traps in erosion prone areas along feeder roads, as specified by the FD Forest Engineer, (1) buffer strips for permanent streams and rivers in Inland / Dipterocarp Forest and Peat Swamp Forest of at least $5 \mathrm{~m}$ in width on either side of the stream or river, and (m) buffer strips for all perennial streams are marked and felling of trees is prohibited (MTCC, 2001).

Within Sabah, the SOPs under this indicator are again quite different, requiring: (a) following the technical specification for reduced impact logging in Schedule F of SFMLA, (b) following the guidelines in the Reference Manual for Timber Harvesting Operations in Commercial Class II Forest Reserves in Sabah., (c) road density of feeder roads not exceeding $20 \mathrm{~m} / \mathrm{ha}$ for tractor skidding area and not exceeding $5 \mathrm{~m} /$ ha for skyline yarding* area, (d) road gradient of feeder roads must not exceed $15 \%$ (or $20 \%$ for sections of less than $150 \mathrm{~m}$ ) but will follow natural benches and topographic features when using existing roads or when newly specified by the FD Forest Engineer, (e) total area occupied by skid trails not exceeding $6 \%$ of the total net logged area, (f) gradient of skid trails not exceeding $47 \%$, (g) right-of-way of feeder roads of less than or equal to $15 \mathrm{~m}$, (h) width of skid trails not exceeding $4.5 \mathrm{~m}$ on slopes up to $20^{\circ}$ and $5 \mathrm{~m}$ on slopes $>20^{\circ}$, (i) carriage way of feeder roads (single lane) with width of 5-6 m, and (j) cross drains* are constructed on roads and skid trails after timber harvesting has ceased, and are $0.5 \mathrm{~m}$ in height, approximately $45^{\circ}$ to the road alignment, and have drain intervals of $20-30 \mathrm{~m}$ for gradient of $5-15^{\circ}$ and $<20 \mathrm{~m}$ for gradient of $>15^{\circ}$ (MTCC, 2001).

\section{(5.6) AVAILABILITY AND IMPLEMENTATION OF HARVESTING PROCEDURES: (A) TO PROTECT THE SOIL FROM COMPACTION BY HARVESTING MACHINERY, AND (B) TO PROTECT THE SOIL FROM EROSION DURING HARVESTING OPERATIONS}

Within Peninsular Malaysia, the SOPs under this indicator are: (a) density of feeder roads of less than or equal to $40 \mathrm{~m} / \mathrm{ha}$, (b) density of skid trails of less than or equal to $300 \mathrm{~m} / \mathrm{ha}$, (c) gradient of feeder roads of less than or equal to $20 \%$, but will follow natural benches and features when using existing roads or newly specified by the Forest Engineer, and (d) skid trails regenerated with appropriate species, mainly indigenous tree species (MTCC, 2001).

\section{AN EXAMPLE MC\&I CERTIFICATION ASSESSMENT}

Three FMUs in Peninsular Malaysia have recently (December 2001) achieved certification* under the 1999 MC\&I, and 'Certificates for Forest Management' have been awarded by the MTCC. These certificates apply to the Selangor FMU, Terengganu FMU and Pahang FMU. The sustainability of the forestry practices undertaken within these FMUs was assessed by SGS (Malaysia) Sdn. Bhd., a subsidiary of Société Générale de Surveillance S.A. of Geneva. The audit of the certified Selangor FMU will be examined as an example (SGS, 2002).

The main assessment of the Selangor state FMU was undertaken over 11-14 July 2000. Several areas of non-conformance were identified, and major Corrective Action Requests (CARs)* were issued which needed to be addressed and closed prior to eligibility for certification against the MC\&I. All major CARs were subsequently addressed by the forest managers and then closed during follow-up visits by SGS in November 2000, making the Selangor FMU eligible for certification against the MC\&I. The few minor infringements of the SOPs (and associated minor CARs) did not preclude the award of the certificate. 
The certification process requires that audits of certified forests are undertaken. During the period 26th March to 5th April 2002, the Selangor FMU was re-assessed (audited), and a final report produced on the 3rd June 2002 (SGS, 2002). How well the forestry practices of the Selangor FMU met the standards of performance for Criterion 5 (Soil and Water) within this audit will be discussed below.

\section{Re-assessment of MC\&I Criterion 5 (Soil and Water) within the Selangor FMU}

As part of indicator 5.1, SGS noted that the forest officers had properly identified the $22.0 \%$ (51,716 ha) of the forest area in the 234,644 ha Selangor PFE managed primarily for the protection of soil and water. This comprised areas gazetted as 'Soil Production Forest' and 'Water Catchment Forest' (PFE Protection Forest) and areas of PFE Production Forest excluded from logging due to height above $1000 \mathrm{~m}$ a.s.l., slopes greater than $40^{\circ}$ and water supply catchments not legally gazetted (SGS, 2002). Outside of the certification requirement, it can be noted that a further 22,025 ha $(9.4 \%)$ of the Selangor PFE is gazetted as other types of PFE Protection Forest, and thus protected from harvesting activities.

SGS noted that all areas having in excess of $40^{\circ}$ slope showed no evidence of harvesting activities. Indeed the whole of Compartment* 75 in the 13,132 ha Ulu Langat FR area was excluded from logging due to the large areas with a slope of more than $40^{\circ}$.

Under indicator 5.3, SGS noted that the forest officers had correctly quantified the proportion of the permanent watercourse in the PFE (as identified on topographic maps). The forest department recorded that $96.45 \%$ of the permanent watercourse was protected during forest harvesting* with a buffer strip. SGS further noted that the minimum width of $5 \mathrm{~m}$ on either side of the channels, as prescribed in the MC\&I, was generally observed, that buffer zone boundary trees were well marked, and no trees were felled within the buffer zone. Only in one location (Compartment 71, Gadong FR), was it noticed that earth had been pushed into a permanent or perennial stream* and trees felled into the buffer zone.

Under indicators 5.3 and 5.4, the SGS assessors noted that 'smaller streams or seasonal streams' were not protected by buffer zones (SGS, 2002). Seasonal or intermittent streams*, like ephemeral streams* are not required to be protected under current MC\&I (MTCC, 2001), and should not have been mentioned in the report. There is some ambiguity in the terminology used in the report, so it is possible that some very small perennial streams, perhaps draining only a few hectares, were not properly protected. This issue will be addressed latter within the chapter.

With regard to the roads (under indicator 5.5), two minor CARs were identified during the re-assessment. Some road-side drains channeled water directly into perennial streams rather than divert it across the surrounding slopes outside the buffer zone (minor CAR SEL-012: SGS, 2002). Secondly, some roads (including skid trails) used for the current harvesting activities utilised old roads which were built too close to streams (minor CAR SEL-013). The high quality of the bridge and culvert construction was, however, recorded.

Under indicator 5.6, SGS noted that cross drains* were not added to all sections of skid trials after cessation of harvesting operations (minor CAR SEL-012); however, this is not a required SOP for Peninsular Malaysia under the current MC\&I. Contractors are, however, sometimes required by the FD Forest Engineer to construct of cross drains on particular sections of feeder roads where erosion problems have occurred. Also under indicator 5.6, SGS noted that in the 5,645 ha Bukit Lagong FR and 3,399.3 ha Batang Kali FR, planting of Leguminosae had been undertaken on road shoulders, skid trails and log landing areas as a soil conservation measure, and that the SOP of feeder road and skid trail density had kept within the MC\&I prescriptions of 40 and $300 \mathrm{~m} / \mathrm{ha}$, respectively (SGS, 2002).

\section{Re-assessment of other MC\&I criteria pertinent to hydrological impacts within the Selangor FMU}

In addition to Criterion 5 (Soil and Water), the protection of the hydrological system is also indirectly covered in Criterion 1 (Enabling Conditions for Sustainable Forest Management) and Criterion 3 (Flow of Forest Produce). Within the re-assessment of the Selangor FMU, national and state laws, policies and regulations were available to provide the framework for the sustainable management of the FMU, including the hydrological aspects (criterion 1: indicator 1.1). Notable legislation pertinent to water-related aspects in the Selangor FMU includes the National Forestry Policy (1978), the National Forestry Act (1984), Forest Rules (1988) for Selangor, the Land Conservation Act (1960) and the Environmental Quality Act (1974). For example, the prescription of an Environmental Impact Assessment (EIA) for sustainable forestry operations is prescribed in the Environmental Quality Act (1974).

While Criterion 3 is aimed at maintaining sustainable timber production, the restrictions on the volume of timber that can be harvested will directly affect: (a) the degree of canopy disturbance and hence the rates of wet-canopy evaporation and transpiration and resultant availability of surface- and soil-water, as well as (b) the intensity of skid trails or cable yarding systems and hence degree of ground disturbance and erosion (see Abdul Rahim and Yusop, 1994; Chappell et al.(a), this volume). In one area (Compartment 18 in the 5,645 ha Bukit Lagong FR) the actual production of $70 \mathrm{~m}^{3} /$ ha did exceed the SOP limit of $61 \mathrm{~m}^{3} / \mathrm{ha}$ for Inland / Dipterocarp Forest with a 30-year cutting cycle (prescribed under indicator 3.4), and so a minor CAR (SEL-008) 
was issued. SGS acknowledged that guidelines for Reduced Impact Logging (RIL)* were available for the Selangor FMU (under indicator 3.7), notably the 'Field Manual for the Selective Management System - Volume 4' (Forestry Department Peninsular Malaysia, 1997), and a draft 'Guidelines for Reduced Impact Logging (January 2002)'. This later document was an amalgamation of SOPs stipulated throughout the existing MC\&I, and SGS stated that this document should be formalised, and as a result issued a minor CAR (SEL-011). Lastly, it was noted that one of the new RIL* methods (involving skidding and rail haulage to the main log landing area) was difficult to apply in Compartment 25 of the 36,161 ha Raja Musa Peat Swamp Forest (SGS, 2002).

\section{ITTO Indicators of the Soil and Water Criterion not currently applied in MC\&I certification}

The Timber Certification Scheme of MTCC was only launched in October 2001 and was done so using a 'phased approach' (Thang, 2002) in which those MC\&I and associated SOPs utilised for certification would be refined with experience. Three of the indicators of the current ITTO Soil and Water Criterion have not been included within the first applications of the revised MC\&I (Thang, 2003). These are:

(a) ITTO indicator 6.2: Extent and percentage of area to be harvested for which off-site catchment values have been defined, documented and protected before harvesting,

(b) ITTO indicator 6.4: Extent and percentage of area to be harvested for which drainage systems have been demarcated or clearly defined and protected before harvesting, and

(c) ITTO indicator 6.9: Existence and implementation of procedures for assessing changes in the water quality of streams emerging from production forests as compared with streams emerging from the same forest type kept free from human intervention.

These indicators will be used for certification and be included in the prevailing MC\&I once field testing of their application has been completed (Thang, 2002). The SGS re-assessment of the Selangor FMU against the current MC\&I also addressed changes needed in the SOPs that would be required for certification of FMUs under the Hallmark Programme of the Keurhout Foundation in the Netherlands. With respect to the omitted ITTO indicator 6.9 , trials of qualitative monitoring of stream water quality at the logging block scale are being undertaken by FD staff, and SGS have suggested that this may need to be formally incorporated within the MC\&I used for certification under the Hallmark Programme (SGS, 2002).

The successful award of certificates of sustainable forestry management* for the Selangor FMU and the other two state FMUs in Peninsular Malaysia, indicates that the current MC\&I and associated SOPs in Peninsular Malaysia are sufficiently unambiguous and readily assessed to allow their use in the forest management certification process. The Forestry Department of Peninsular Malaysia does, however, suggest that this process could be improved if there were to be greater supervision of field operations by FD staff, and if contractors and FD field staff were to be given more training. The open, transparent and ever improving process of forest certification facilitates the continual re-evaluation of the scientific basis of the criteria, indicators and standards of performance. In light of the review of selective forestry impacts on tropical hydrological systems detailed by Chappell et al.(a) (this volume), how consistent are the current MC\&I used for certification of Malaysia's rainforests?

\section{CONSISTENCY WITH CURRENT HYDROLOGICAL SCIENCE}

Chappell et al. (a) (this volume), demonstrated that the greatest relative impact of selective harvesting of tropical forest on the hydrological system, is potentially the acceleration of sediment flows. This relates to a combination of increased surficial erosion and mass movements in disturbed forest areas. The resultant input of sediment into rivers leads to damage to fish populations (MartinSmith, 1998), reduced quality of water supplies, reductions in channel capacity affecting flood risk and boat traffic (Sheffield et al., 1995), and the inundation of offshore corals (MacDonald et al., 2001). Impacts on water-supply availability, losses of vapour to the atmosphere, river flashiness, and nutrient losses through enhanced leaching from soil and litter, while observable, had a smaller magnitude of relative change (Chappell et al. (a), this volume).

There are several features associated with tropical, selective forest harvesting operations where the hydrological impacts could arise and where protective measures are currently incorporated or should be considered for incorporation. These are: (a) main and secondary roads, (b) feeder roads, (c) skid trails, where present, (d) stream buffer zones (SBZs), and (e) areas of disturbed forest canopy.

\section{Main and secondary forest roads}

Under the 'Forest Road Specification for Peninsular Malaysia' (Forestry Department Peninsular Malaysia, 1999), a main road is a road in/out of a forest area that is designed to accommodate a high number of vehicles (notably timber haulage lorries) to transport logs to the sawmill. A secondary road* is a road connecting a feeder road and main road for the purpose of log transport, rehabilitation and monitoring works (Forestry Department Peninsular Malaysia, 1999). Main roads are normally dual lane (with a 
formation width of 9-12 m), while secondary roads are single lane (with a formation width of 8-10 m). The main and secondary forest roads are permanent roads that normally have an all-weather running surface (e.g. gravel). For the forest management company, the most costly enterprise is the construction and maintenance of the permanent main and secondary forest roads (Putz, 1994; W. Sinun, Forestry Division of the Sabah Foundation, pers. comm.). It is in the company's interest to build permanent roads that are less likely to become un-trafficable due to surficial gullying, failure by mass movements or bridge collapse. The standards for main and secondary forest roads are normally high (Lim, 1999), though not as high as those of asphaltic, public highways (see e.g. Transport Research Centre, 1993) as the cost of the road construction would be higher than the revenue generated from sustainable timber production (D. H. K. Chua, Sarawak Forest Department, pers. comm.). Thus some enhanced risk of sediments entering rivers due to gradual road surface deterioration and periodic slope failure is likely. The gravel surfacing of main and secondary roads should offer some protection from erosion of fine sediments into watercourses. Soil exposure and disturbance around and below bridges or culverts could be significant point inputs of sediment into rivers, however, even within properly managed / certified forests (see the related work of Madej, 2001).

\section{Forest feeder roads}

Feeder roads classified by the Forestry Department Peninsular Malaysia (1999) in contrast to the main and secondary forest roads are temporary roads that are used to transport logs out from a harvest site. These roads are typically unsurfaced and used to transport timber from the annual coupe and used only during timber extraction. From a commercial perspective, feeder roads need to be built to a sufficient standard to allow timber extraction during the logging of a single harvesting coupe. Deterioration of the road after this time only becomes a commercial issue after some 30-60 years when a further cut can be taken. Regulations governing the construction and maintenance of feeder roads are, therefore, required to lessen the short- and medium-term environmental impacts of road erosion and mass movement. Such regulations are contained in the standards of performance of the MC\&I Soil and Water Criterion, particularly those under Indicator 5.5 on road lay-out. Within Peninsular Malaysia, these SOPs aim to: (a) minimise the risk of erosive flows developing on the feeder road (refer to earlier sections: $5.5 \mathrm{~d}-\mathrm{h}$ ), (b) minimise the risk of culvert and bridge failure which would lead to accelerated erosion and mass movement (5.5ij), and (c) capture eroded sediments before they reach the stream (5.51). Within the report of the audit of the Selangor FMU, SGS noted that some roads not originally built to current MC\&I specifications for slope and proximity to streams had been re-opened (SGS, 2002). When considering this issue,

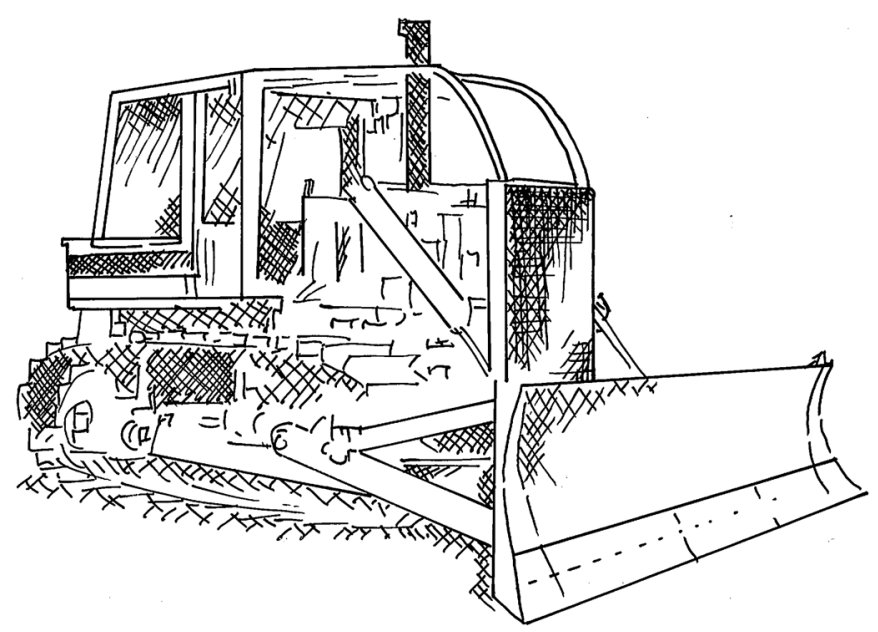

Figure 36.1 Common types of ground skidding equipment (Sist et al., 1998).

it should be noted that abandoned feeder roads can continue to generate sediment as a result of log culvert collapses and slope failure (Chappell et al., 1999). Thus the combined effect of sediment generated from an abandoned feeder road and from a newly constructed road (built to current MC\&I and specification of the Forestry Department Peninsular Malaysia, 1999), may in certain circumstances, generate more sediment than re-opening a feeder road having a lower specification. Careful consideration of the specific site details needs to be made in such cases. The restriction of feeder road density and size (5.5ac), will restrict the extent of slope cutting, stream crossings and soil exposure within an area and so restrict the magnitude of erosion and mass movement. It also restricts the amount of canopy disturbance and resultant reductions in wet-canopy evaporation and transpiration (Asdak, et al., 1998; Chappell et al. (a), this volume; van Dam, 2001), and thus increases in overland flow and/or subsurface water.

\section{Skid trails}

Skid trails are the routes from the main, secondary or feeder roads made by wheeled skidders, crawler skidders or crawler tractors (Sist et al., 1998) Figure 36.1). Example skid trail networks are shown in Figure 36.2 (from Dykstra and Heinrich, 1996) and in Chappell et al. (a) (this volume). In Malaysia, ground skidding* is the principal method for moving logs from where a tree is felled to the landing area* (Figure 36.2) where the timber is loaded onto haulage lorries (Jusoff and Mustafa, 1996). Logs are dragged behind the skidder or tractor using a cable and winch.

Where there is a high local timber density and where slopes are relatively steep, the more expensive skyline yarding* system can be used to complement ground skidding in other parts of the logging coupe (Nydegger, 1998). With this method, each $\log$ is normally lifted above the forest canopy at the felling 


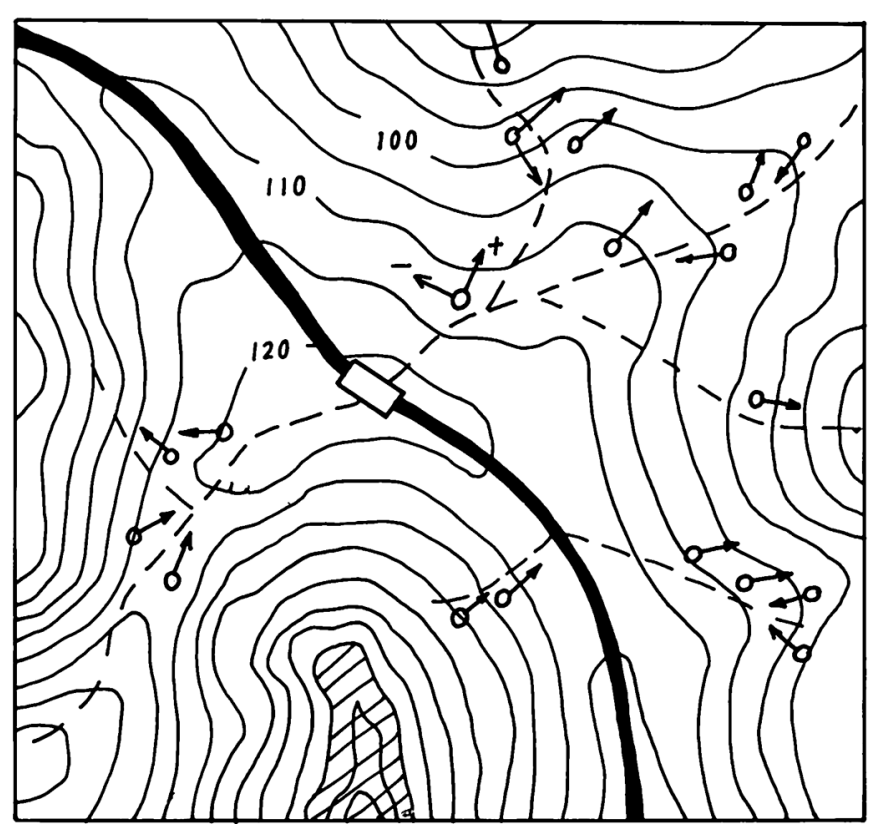

Figure 36.2 Example of a tactical logging map (scale 1:2000, $5 \mathrm{~m}$ contour lines) issued after the pre-harvesting inventory. Heavy solid line indicates a main, secondary or feeder road and dashed lines present skid trails*. The open rectangle is a log landing area*. Circles indicate trees to be felled, with the arrows showing the planned direction of felling. The hatched area is a stream buffer zone.* (After Sist et al., 1998.)

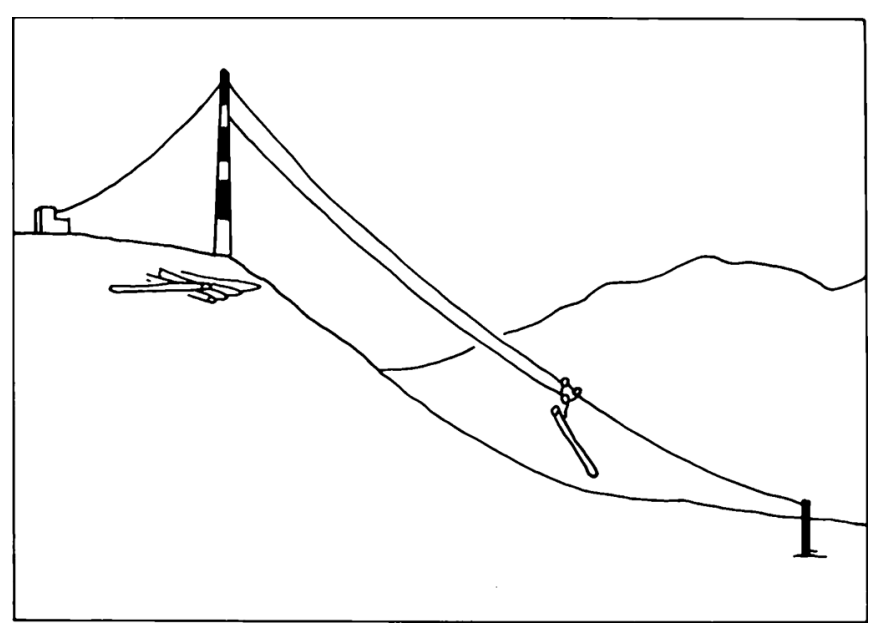

Figure 36.3 An example of a skyline with fully suspended logs (Sist et al., 1998).

location to be lowered only on reaching a landing area by a road (Figure 36.3). Aerial logging*, where the cut timber is lifted by large payload helicopters (e.g. the Sikorsky S-64E skycrane) to the landing area on the roadside, has been carried out by the Sarawak Forestry Department (Chua, 1996; 2001). Aerial logging and skyline yarding with their more modest ground disturbance (Dykstra and Heinrich, 1996) have, however, not replaced ground skidding due to the significantly greater costs of their application (Conway, 1982; Dykstra and Heinrich, 1996). The use of skyline yarding in combination with ground skidding has been shown to be profitable within the Deramakot area of Sabah (Mannan and Awang, 1997).

Un-regulated skidder use, where new trails are cut to fetch individual logs, slopes are extensively cut with the skidder's front blade, and where timber is skidded down very steep slopes, would lead to considerable opening of the forest canopy (Bruijnzeel, 1992; Dykstra and Heinrich, 1996; Pinard and Putz, 1996) and hence reductions in wet-canopy evaporation and transpiration, giving greater amounts of overland flow and subsurface water. Poor management where skidders cross small rivers without the use of bridges or culverts would greatly disturb soils and sediments within and by streams, and would, therefore, greatly enhance stream sediment loads (see related studies by Grayson et al., 1993; Brown, 1994). Ground skidding activities on steep slopes within Malaysia have been shown to give greater soil disturbance in comparison with those on shallower slopes (Jusoff, 1990). This observation justifies the prohibition of such activities on slopes greater than $40^{\circ}$ under indicator 5.2 and 5.4 of the MC\&I (MTCC, 2001). The research indicates that significant reductions in soil erosion could be gained if the upper slope limit were to be reduced below $40^{\circ}$. Further reductions in soil erosion may be obtained if MC\&I required that roads were only built near ridges, so that logs were only skidded uphill (Bruijnzeel, 1992).

As skid trails are used to bring logs to a central point (i.e. the landing area) for subsequent bulk transport with lorries, a greater density of skid trails relative to main, secondary and feeder roads is expected, thus giving a greater potential for canopy disturbance. Compliance with Peninsular Malaysia's MC\&I means that these potential impacts on the canopy can be checked by restricting the density of the skid trails to less than or equal to $300 \mathrm{~m} / \mathrm{ha}$ (Indicators 5.5 and 5.6), by restricting harvesting* operations to below $1,000 \mathrm{~m}$ and $40^{\circ}$ slopes (indicators 5.2 and 5.4), by planting indigenous trees on skid trials after use (indicator 5.6), and by preventing skidder access (or cutting) near to small and large rivers (i.e. Stream Buffer Zones or SBZs; indicators 5.3 and 5.5). Direct input of sediments from skid trails into small and large rivers with permanent flows is similarly checked by the designation of SBZs.

\section{Stream buffer zones}

For forest management certification within Malaysia, stream buffer zones (SBZs) must be defined on permanent watercourses (i.e. streams and rivers). Within the stream buffer zones, skidder use is barred and tree cutting is prohibited (MTCC, 2001). Only bridges for main, secondary or feeder roads are permitted. In addition to the ecological benefits of maintaining riverine microclimate, habitat and seed pools, limiting canopy and terrain 
disturbance, SBZ delineation will limit stream bed and bank erosion of the protected channel (see review of Wenger, 1999).

Within Peninsular Malaysia, all reaches with permanent or perennial flows* should be buffered, though comments made by SGS during their certification of the Selangor FMU (SGS, 2002) may, however, indicate that very small (e.g. $<1 \mathrm{~m}$ wide) permanent / perennial streams may not always be protected. Outside Peninsular Malaysia, e.g. in Sabah, streams with a permanent flow but with a width of less than $5 \mathrm{~m}$, are not required to be buffered under current regulations.

Within the Danum Valley research area of Sabah State, perennial streamflow can be observed to be generated by areas as small as 1 ha (Chappell et al., 1999), with streams having channels of about $5 \mathrm{~m}$ width being generated by areas of between 3 to $10 \mathrm{~km}^{2}$ (300-1,000 ha). First, second and perhaps third order headwater streams (Strahler, 1957) would, therefore, not be protected by buffer zones in this state. Similar channel-width based limits to buffer zone designation are present within the forestry guidelines of other countries having tropical forest (e.g. Cassells et al., 1984; Sist et al., 1998). Using the example of the Danum Valley area, if all permanent / perennial streams were to be protected with buffer zones with $10 \mathrm{~m}$ either side of the channel (20 m total width), timber harvesting would not be permitted within $13 \%$ of the area (assuming a drainage density of $6.5 \mathrm{~km} / \mathrm{km}^{2}$ as observed for the 44 ha Baru catchment in the Danum area: Chappell et al., 1999). Chappell et al. (1999) and Chappell et al. (2003) show high rates of sediment delivery from some perennial streams draining areas as small as $1-5$ ha (i.e. a range from 14 to $1,467 \mathrm{t} \mathrm{km}^{-2} \mathrm{yr}^{-1}$ ). Similarly, Pearce et al. (1980), observing the effectiveness of buffer strips placed only on larger streams in the Tawhai State Forest (New Zealand), showed that un-buffered streams draining areas ranging from 1.6 to 8.3 ha can add significant quantities of sediment to the buffered main channels. As current MC\&I already require the protection of all permanent streams with buffer zones, perhaps greater assurance that this is done could be achieved if FD field staff and indeed third party assessors of forest certification were to be given training by forest hydrologists in the (field and map) identification of perennial streams. Greater erosion protection would be achieved in the Malaysian state of Sabah, and indeed within several other tropical countries, if the channel-width limit for those perennial streams to be protected were to be removed.

The SGS assessors of the Selangor State FMU implied that even intermittent* and ephemeral* ${ }^{*}$ streams should be protected by buffer zones (SGS, 2002). Others (e.g. Durst, 1999) have similarly suggested that all channels should be protected. If all ephemeral, intermittent and perennial channels within the Danum area had $20 \mathrm{~m}$ total width SBZs, then timber harvesting would not be permitted within $40 \%$ of the region purely on the basis of SBZs (assuming a total drainage density of $20 \mathrm{~km} / \mathrm{km}^{2}$ : Walsh and Bidin, 1995). This would also make the areas outside the SBZ largely inaccessible. This, combined with the reduced timber volumes available, would make harvesting within this region uneconomic. Given the high drainage density within most equatorial forest regions (Gregory, 1976; Morgan, 1976; Walsh, 1996) such a policy may make commercial forestry uneconomic within these regions also, and thus inconsistent with the fundamental 'PeoplePlanet-Profit' principles of sustainable management*. Indeed suggesting any environmental protection measures that might have a significant impact on the viability of commercial forestry should be assessed for their economic impacts (see review of RIL costs in Tay, 1999; Hammond et al., 2000; Putz et al., 2000; Bull et al., 2001 ) prior to their imposition, particularly by non-producer countries. Chappell et al. (1993) have shown, via the monitoring of 14 nested contributory areas within the Baru catchment, that greater sediment yields (per unit area) are generated by perennial channels (1st to 3rd order basins), than by the channels with intermittent or ephemeral flows. This may imply that there is less hydrological justification for buffering intermittent and ephemeral channels, in comparison to all reaches of perennial channel. In addition to the greater training required for foresters in the identification of perennial channels, there is a need to generate simple methods for this procedure. Such channels could be identified by:

(a) the visual observation of the presence of water in the channels during inter-storm periods, or

(b) a minimum contributory area (e.g., 1 ha), or

(c) an index of minimum contributory area and slope angle.

Option (b) could be identified using Geographical Information System (GIS) methods applied to the digital Harvest Plan Maps currently used for managing certified / RIL forests (e.g. Sabah Forestry Department, 1997). An even better predictor of the start of a perennial stream would be gained by combining a minimum contributory area with the effect of the slope characteristics within the contributory areas (Option c). Topographic or wetness indices (see Barnes, this volume; Chappell et al. (b), this volume) could be readily incorporated within the same GIS framework as in Option (b).

Although some of the channels supporting intermittent or ephemeral flows within Malaysia's headwaters PFEs are already protected by being within areas that are either above $1,000 \mathrm{~m}$ or on slopes $>40^{\circ}$, it must be concluded that under the present regulations many zero- to second-order streams are not protected. Indeed, Bren (2000) has shown that the use of fixed buffer widths leads to underprotection of streamhead hollows and other places where flows tend to converge (places with high 'hydrologic loading'), and to overprotection of slopes further downstream that tend to produce more divergent patterns of flow (places with low hydrologic loading). Bren (2000) explored the usefulness of two measures of flow convergence for buffer zone delineation, viz. specific area and a slope index (both derived from digital elevation 
models) and their respective threshold values. Although areas of flow convergence received (more than) adequate protection in this way, downstream areas with low hydrologic loading often did not get any protection at all. In addition, the results were not always predictable and showed large spatial variability, rendering the method less suitable from an administrative point of view. Moreover, despite the fact that areas with high hydrologic loading were identified, the method by itself did not meet the criteria for buffer zone designation. Finally, the requirements for detailed topographic information as well as computational skills and hardware are such that convergence-based buffer zone delineation must be considered feasible only for very well-equipped and staffed organisations. As such, prospects for application in remote tropical terrain are very limited for the time being (cf. Cassells and Bruijnzeel, this volume).

\section{Areas of disturbed forest canopy}

The greater the disturbance to the canopy of Natural Forest, the greater is the likelihood of changes to the overall forest albedo, aerodynamic roughness and Leaf Area Index (LAI), and hence the greater likelihood of changes in wet-canopy evaporation and transpiration losses (van Dam, 2001). Research outside the tropics (e.g. Swanson and Dyrness, 1975; Sidle et al., 1985) suggests that reducing the components of evapo-transpiration with vegetation removal, increases subsurface water levels and hence the risk of slope failure. Where surficial erosion is an issue, the greater is the area of soil exposed along skid trails and feeder roads during timber cutting and extraction, and hence the greater potential for surficial erosion processes. Larger rates of canopy disturbance are also likely to give greater losses of nutrients via greater leaching (Brouwer, 1996; Yusop, 1996). Adherence to the MC\&I specifications reduces the degree of canopy disturbance not only by limiting the density and size of skid trails and feeder roads (indicators 5.5 and 5.6), prohibiting felling and skidding activities in areas over $1,000 \mathrm{~m},>40^{\circ}$ slopes (indicator 5.2 and 5.4) and within stream buffer zones (indicator 5.3), but also by limiting the volume of the annual cut (indicator 3.4). The work of Pinard et al. (1995) and Pinard and Putz (1996) in the RIL trial areas of the Sabah Foundation concession in Sabah state, clearly demonstrates the value of such guidelines for the quality of the forest canopy remaining after harvesting. Similar studies are identified in the review of Putz et al. (2000).

\section{CONCLUSIONS AND RECOMMENDATIONS}

The MC\&I currently used for assessing the sustainability of forestry practices used within Malaysia's rainforest address directly the protection of the hydrological system within MC\&I Criterion 5: Soil and Water. The associated indicators, activities and standards of performance clearly address the problem of accelerated losses of sediment into rivers. This focus is important, given that Chappell et al. (a) (this volume) identify accelerated erosion and mass movement as having the greatest potential for relative change to the hydrological system as a result of forestry operations within areas of tropical rainforest maintained for sustainable timber production.

In the case of Peninsular Malaysia, the standards of performance that the State Forest Officers, timber concessionaires and logging companies need to follow and that are used by the national or international certification organisations to judge the (physical) environmental sustainability of these operations are very detailed and largely unambiguous. Similarly clear and simple lists of SOPs (MTCC, 2001) should be stated for the East Malaysian states of Sabah and Sarawak. The current debate between international assessors and local foresters over what is and what should be the SOPs (e.g. SGS, 2002), is valuable as guidelines may need to differ slightly with local site conditions (Nussbaum et al., 2002), and should be continually refined (Thang, 2002). In this respect, we believe that the definition of stream buffer zones (indicators 5.3 and 5.5), is a key area for discussion and further academic and applied research. We suggest that such research would lead to the clearest results if landscape-scale (at least $0.5-50 \mathrm{~km}^{2}$ ) impacts on sediment delivery (derived from stream monitoring: see Abdul Rahim et al., 1997) were to be combined with statistically meaningful sets of plot erosion/mass movement studies within riverside areas (Chappell et al. (a), this volume).

The standards of performance pertinent to the hydrological system that are used within Malaysia, or within tropical rainforests elsewhere (e.g. Dykstra and Heinrich, 1996; Armatage, 1996; Sist et al. 1998) are based largely on an assimilation of preexisting guidelines (Dykstra, 1999), the field experience of FD Forest Engineers, civil engineering practice covering road design, general hydrological concepts found within the literature (e.g. Hewlett, 1982), a few processes or applied hydrology case studies from other regions of the world (e.g. Gilmour, 1977; Swanson and Dyrness, 1975; Bonell et al., 1983) and critical reviews of scientific data (Bruijnzeel, 1990, 1992), but very few robust scientific studies undertaken within similar physiographic locations using similar forestry manipulations (Chappell et al. (a), this volume). More hydrological field studies are needed within specific physiographic-climatic-vegetation regions (e.g. the Maritime Continent of Malaysia-Indonesia-Philippines with its relatively high relief, unstable soils and sensitivity to monsoon and ENSO cycles) that produce clear results of the landscape-scale, hydrological benefits of specific RIL practices. We suggest that such research should address the hydrological value and benefits of: 
(a) perennial stream identification for improved stream buffer zone definition,

(b) maximum permitted skid trail / feeder road densities (Pinard et al., 2000),

(c) maximum allowable slope for ground skidding operations (Yusop, 1990),

(d) benefits of uphill versus downhill skidding (Bruijnzeel, 1992), and the

(e) required use of cross drains* at regular intervals along forest roads (Sabah Forestry Department, 1998b; Sist et al., 1998).

With such data, the (physical) environmental benefits of applying specific SOPs can be judged more accurately against the economic considerations that are an equal part of sustainable forestry management (ITTO, 1999; Tay, 1999; Hammond et al., 2000; Putz et al., 2000; Bull et al., 2001; Thang, 2003).

Given that so little landscape-scale data (i.e. catchment waterbalances, river regimes, river sediment and nutrient loads) are available to evaluate the impacts of specific forestry practices, the incorporation of quantitative monitoring of river water quality (ITTO indicator 6.9) into the MC\&I used for certification would help forest hydrologists to define the SOPs and associated RIL systems that have real benefits on the landscape-scale, hydrological system of Malaysia and other tropical regions with similar characteristics.

It is clear that the guidelines for reducing the impacts of logging operations within Malaysia's rainforests have developed considerably, particularly in recent years. The openness and transparency generated by the forest management certification process gives the forest hydrologist the opportunity to add substantially to the science that underpins the ever-improving forestry guidelines.

\section{APPENDIX 36.1 \\ GLOSSARY OF FORESTRY TERMS USED}

Aerial logging Logs are moved from the stump to the landing area* by being lifted by helicopter or balloon (Conway, 1982).

Activity An action to be taken for compiling quantitative or qualitative information required to achieve the desired result of the Indicator* (MTCC, 2001).

Annual coupe Area of forest to be harvested within a period of one year (Sist et al., 1998).

Certification This is the process of establishing whether or not the forestry System Standard and or Standard of Performance* has been met (Nussbaum et al., 2002).

Compartment $\mathrm{A}$ fragment of homogeneous forest as regards its basic natural features, and requiring uniform silvicultural management, delineated in accordance with the principles of forest management.
Corrective Action Requests (CARs) A statement of non-compliance with SOPs that must be corrected before certification (major CAR) or within a few months after (minor CAR).

Criterion An aspect that is considered important by which sustainable forest management may be assessed. A criterion is accompanied by a set of related Indicators* (ITTO, 1999).

Cross drain In tropical areas, this is a trench and/or bund constructed across feeder roads* and/or skid trials* after timber harvesting has ceased, to divert surface water from the road surface or side drain.

Ephemeral stream A stream that flows only during storm events (Dingman, 1994). Compare with the definition for a perennial stream* and intermittent stream*.

Feeder road A temporary road that is used to transport logs out from a harvest site (Forestry Department Peninsular Malaysia, 1999).

Forest Management Unit (FMU) A clearly defined forest area, managed to a set of explicit objectives and according to a long-term management plan (ITTO, 1999).

Harvesting Timber harvesting operations include the construction of forest roads, tree cutting, ground skidding, cable yarding, and timber haulage.

Indicator A quantitative, qualitative or descriptive attribute that, when periodically measured or monitored, indicates the direction of change (ITTO, 1999).

Intermittent stream A stream that flows only during the wet season (Dingman, 1994). Such stream types may not be common in equatorial rainforests when rainfall seasonality is small. Compare with the definition for permanent stream* and ephemeral stream*.

Landing area A roadside area used for the temporary storage of logs before loading on to haulage lorries, rail or water transportation. These areas are also called 'log landing areas', 'loading areas', 'logyards' and 'mantau' (in Malaysia).

Main road A road in/out of a forest area that is designed to accommodate a high number of vehicles (notably timber haulage lorries), normally having dual carriageway, to transport logs to timber processing mills, especially sawmills (Forestry Department Peninsular Malaysia, 1999).

Malayan Uniform System (MUS) A 'monocyclic' harvesting system in which the next cut is from seeds, seedlings or saplings (see Wyatt-Smith et al., 1964; Dawkins and Philip, 1998; Putz et al., 2000).

Natural Forest Forest land composed of indigenous trees, not planted by man, which is further classified using the criteria of forest formation (or type), degree of human disturbance or modification, and human interference (ITTO, 1999).

Perennial stream A stream that flows all year (Dingman, 1994); also called a permanent stream. Compare with the definition for an intermittent stream* and ephemeral stream*.

Permanent Forest Estate (PFE) Land, whether public or private, secured by law and kept under permanent forest cover. This includes 
land for the production of timber and other forest products, for the protection of soil and water, and for the conservation of biological diversity, as well as land intended to fulfill a combination of these functions (ITTO, 1999).

Reduced Impact Logging (RIL) The intensively planned and carefully controlled implementation of harvesting operations to minimise the impact on forest stands and soils, usually in individual tree selection cutting (Bull et al., 2001).

Secondary road A road connecting a feeder road and main road for the purpose of $\log$ transport, rehabilitation and monitoring works (Forestry Department Peninsular Malaysia, 1999), normally having only a single carriageway.

Selective Management System (SMS) A 'polycyclic' harvesting system in which the next cut is from trees of intermediate size (e.g. 20-40 cm dbh) at the time of first cutting, (Dawkins and Philip, 1998; Putz et al., 2000).

Skidding Logs are moved from the stump to the landing area* by being dragged by wheeled skidders, crawler skidders or crawler tractors (Conway, 1982). Also called 'ground skidding'.

Skid trail A route from the main, secondary or feeder roads made by wheeled skidders, crawler skidders or crawler tractors (Conway, 1982; Sist et al., 1998). These routes are also called 'skid tracks' and 'snig tracks'.

Skyline yarding Logs are moved from the stump to the landing area* by being lifted on a wire rope suspended between two or more points (after Conway, 1982). To minimise ground and canopy disturbance, skylines that fully suspend the logs are preferable (Dykstra and Heinrich, 1996).

Standard of Performance (SOP) A set of requirements used as benchmarks to measure the attainment of a particular Indicator* (MTCC, 2001).

Stream Buffer Zone (SBZ) An area adjoining permanent streams where harvesting activities are restricted and/or prohibited.

Sustainable forest management Sustainable forest management is the process of managing forest to achieve one or more clearly specified objectives of management with regard to the production of a continuous flow of desired forest products and services without undue reduction of its inherent values and future productivity and without undue undesirable effects on the physical and social environment (ITTO, 1999). Thus the three elements of sustainable management of People-Planet-Profit (PPP) are explicitly included.

Yarding Logs are moved from the stump to the landing area* by being lifted on a wire rope either by highlead, skyline* or shotgun methods (after Conway, 1982).

\section{References}

Abdul Rahim, N. and Yusop, Z. (1994). Hydrological response to selective logging in Peninsular Malaysia and its implications on watershed management. In Proceedings of the International Symposium on Forest Hydrology, pp. 263-274. Tokyo, Japan, October 1994.
Abdul Rahim, N., Wan Mohd, W. R., Yusop, Z., Chan, H. T., Lim, H. F., Ratnam, L., Appanah, S., Mohd Sharif, A. H., Kasran, B., Manokaran, N., Yahya, N. A., and Yaacob, A. (1997). EIA Guideline for Harvesting of Natural Forests. FRIM Technical Information Handbook No. 14.

Armitage, I. (1998). Guidelines for the management of tropical forests 1 . The production of wood. FAO forestry paper No. 135. Rome: Food and Agriculture Organisation.

Asdak, C. Jarvis, P. G., van Gardingen, P. and Fraser, A. (1998). Rainfall interception loss in unlogged and logged forest areas of Central Kalimantan, Indonesia. Journal of Hydrology, 206: 237-244.

Bidin, K. (2001). Spatio-temporal variability in rainfall and wet-canopy evaporation within a small catchment recovering from selective tropical forestry. Unpublished $\mathrm{PhD}$ thesis. Lancaster: University of Lancaster.

Bonell, M., Gilmour, D. A., and Cassells, D. S. (1983). Runoff generation in tropical rainforests of north-east Queensland, Australia, and its implications for land use management. In Proceedings of the symposium on the hydrology of humid tropical regions, IAHS Publ. 140, ed. R. Keller, pp 287-297. Paris: IAHS

Bren, L. J. (2000). A case study in the use of threshold measures of hydrologic loading in the design of stram buffer strips. Forest Ecology and Management, $132,243-257$.

Brouwer, L. C. 1996. Nutrient cycling in pristine and logged tropical rainforest. Unpublished $\mathrm{PhD}$ thesis. Utrecht: Utrecht University.

Brown, K. J. (1994). Riverbed sedimentation caused by off-road vehicles at river fords in the Victorian Highlands, Australia. Water Resources Bulletin, 30: 239-250.

Bruijnzeel, L. A. (1990). Hydrology of moist tropical forest and effects of conversion: a state of the art review. Paris: UNESCO.

Bruijnzeel, L. A. (1992). Managing tropical forest watersheds for production: where contradictory theory and practice co-exist. In Wise Management of Tropical Forests, Proceedings of the Oxford Conference on Tropical Forests 1992, eds. F. R. Miller and K. L. Adam. pp. 37-75. Oxford : Oxford Forestry Institute (University of Oxford)

Bull, G. Q., Pulkki, R., Killmann, W., and Schwab, O. (2001). Does it cost or does it pay?: An investigation of the costs and benefits of reduced impact logging. Tropical Forest Update, 11(2). Yokohama: International Tropical Timber Organisation.

Cassells, D. S., Gilmour, D. A., and Bonell, M. (1984). Watershed forest management practices in the tropical rainforests of north-eastern Australia. 289-298. In Effects of Land Use on Erosion and Slope Stability, C. L. O'loughlin and A. J. Pearce (eds). Vienna: IUFRO.

Chappell, N. A., McKenna, P., Bidin, K., Douglas, I. and Walsh, R. P. D. (1999). Parsimonious modelling of water and suspended-sediment flux from nestedcatchments affected by selective tropical forestry. Philosophical Transactions of the Royal Society of London Series B., 354: 1831-1846.

Chappell, N. A., Bidin, K. and Tych, W. (2001). Modelling rainfall and canopy controls on net-precipitation beneath selectively-logged tropical forest. Plant Ecology, 153: 215-229.

Chappell, N. A., Yusop, Z. Abdul Rahim, N., Tych, W., and Kasran, B. (a). Spatially-significant effects of selective tropical forestry on water, nutrient and sediment flows: a modelling-supported review. this volume.

Chappell, N. A., Bidin, K, Sherlock, M. D., and Lancaster, J. W. (b). Parsimonious spatial representation of tropical soils within dynamic rainfall-runoff models. this volume.

Chappell, N. A., Douglas, I., Hanapi, J. M., and Tych, W. (2003). Source of suspended-sediment within a tropical catchment recovering from selective logging. Hydrological Processes, in press.

Chua, D. K. H. (1996). Helicopter logging lifts off in Sarawak. Tropical Forest Update, 6(3). Yokohama: International Tropical Timber Organisation.

Chua, D. K. H. (2001). Helicopter harvesting in the hill mixed dipterocarp forests of Sarawak. Paper presented at the International Conference on Application of Reduced Impact Logging to Advance Sustainable Forest Management - Constraints, Challenges and Opportunities, 26th February - 1st Match 2001, Kuching.

Condit, R., Ashton, P. S., Manokaran, N., LaFrankie, J. V., Hubbell, S. P., and Foster, R. B. (1999). Dynamics of the forest communities at Pasoh and Barro Colorado: comparing two 50-ha plots. Philosophical Transactions of the Royal Society of London Series B. 354: 1739-1748.

Conway, S. (1982). Logging Practices. San Francisco : Miller Freeman Publications.

Dawkins, H. C., and Philip, M. S. (1998). Tropical moist forest silviculture and management: A history of success and failure. Wallingford: CAB International. 
Dingman, S. L. (1994). Physical Hydrology. Englewood Cliffs: Prentice Hall.

Douglas, I., Greer, T. Bidin, K., Sinun, W., and Wong, W. M. (1993). Impact of roads and compacted ground on post-logging sediment yield in a small drainage basin. In Hydrology of Warm Humid Regions, 213-218, J. S. Gladwell (ed), Publication 216. Wallingford: IAHS Press.

Douglas, I., Greer, T., Sinun, W., Anderton S., Bidin, K., Spilsbury, M., Jadda, S., and Azman, S. (1995). Geomorphology and rainforest logging practices. In Geomorphology and Land Management in a Changing Environment, eds. D. F. M. McGregor and D. A. Thompson. Chichester: Wiley.

Douglas, I. Bidin, K., Balamurgan, G., Chappell, N. A., Walsh, R. P. D., Greer, T. and Sinun, W. (1999). Role of extreme events in the impacts of selective tropical forestry on erosion during harvesting and recovery phases at Danum Valley, Sabah. Philosophical Transactions of the Royal Society of London Series B., 354: 1749-1761.

Durst, P. B. (1999). Code of Practice for Forest Harvesting in Asia-Pacific. RAP Publication 1999/12. Rome: Food and Agriculture Organisation.

Dykstra, D. P. (1999). Codes of Forest Practice: Historical background and conceptual framework of the FAO Model Code of Forest Harvesting Practice. In Research on environmentally sound forest practices to sustain tropical forests. Rome: Food and Agriculture Organisation.

Dykstra, D. P. and Heinrich, R. (1996). FAO model code of forest harvesting practice. Rome: Food and Agriculture Organisation.

FAO. (1997). Asia-Pacific Forestry Sector Outlook Study: Country Report Malaysia. Working Paper APFSOS/WP/07. Rome: Food and Agriculture Organisation.

Forest Stewardship Council. (2000). FSC Principles and Criteria. Document 1.2. Oaxaca: Forest Stewardship Council.

Forestry Department Peninsular Malaysia. (1997). Field Manual for Selective Management System - Volume 4. Kuala Lumpur: Forestry Department Peninsular Malaysia.

Forestry Department Peninsular Malaysia. (1999). Specification of Forest Roads for Peninsular Malaysia. Kuala Lumpur: Forestry Department Peninsular Malaysia.

Gilmour, D. A. (1977). Effect of rainforest logging and clearing on water yield and quality in a high rainfall zone of North-east Queensland. In Symposium on The Hydrology of Northern Australia, Brisbane. pp. 156160. Old National Conference Publication No. 7715, Institute of Engineers (Australia)

Grayson, R. B., Haydon, S. R., Jayasuriya, M. D. A., and Finlayson, B. L. (1993). Water-quality in mountain ash forests - separating the impacts of roads from those of logging operations. Journal of Hydrology, 150: 459480.

Gregory, K. J. (1976). Drainage networks and climate. 289-315. In Geomorphology and Climate. E. Derbyshire (ed). London: Wiley.

Hammond, D. S., Van der Hout, P., Zagt, R. J., Marshall, G., Evans, J., and Cassells, D. S. (2000). Benefits, bottlenecks and uncertainties in the pantropical implementation of reduced impact logging techniques. International Forestry Review, 2: 45-53.

Hewlett, J. D. (1992). Principles of Forest Hydrology. Athens: University of Georgia Press.

Holmes, A. (1995). Baseline hydrological survey and hydrometric network. In Proceedings of the Workshop on Topography, Soil, Hydrology and Forest Reservation, 9 May 1995, Kuching. Kuching: Sarawak Forest Department.

Huth, A., and Ditzer, T. (2001). Long-term impacts of logging in a tropical rainforest - a simulation study. Forest Ecology and Management, 142: 3351 .

ITTO. (1999). Manual for the Application of Criteria and Indicators for Sustainable Management of Natural Tropical Forests - Part B / Forest Management Unit Indicators. Policy Development Series No. 10. Yokohama: International Tropical Timber Organisation.

Jusoff, K. (1990). A survey of soil disturbance from tractor logging in a hill forest of Peninsular Malaysia, 16-21, In Proceedings of the Conference on Malaysian Forestry and Forest Products Research, ed. S. Appanah, F. S. P. $\mathrm{Ng}$, and R. Ismail, 3-4 October 1990. Kepong: Forest Research Institute of Malaysia.

Jusoff, K. and Mustafa, N. M. S. N. (1996). Guidelines on logging practices for the hill forest of Peninsular Malaysia. In Forest Codes and Practice. FAO Forestry Paper No. 133. Rome: FAO.

Lai, F. S. (1992). Sediment and solute yields from logged, steep upland catchments in Peninsular Malaysia, Unpublished PhD thesis. Manchester: University of Manchester.
Leigh, C. H. (1982). Sediment transport by surface wash and throughflow at the Pasoh Forest Reserve, Negri Sembilan, Peninsular Malaysia. Geografiska Annaler A, 64, 171-179.

Lim, K. Y. (1999). The role of road infrastructures in the tropical forests of Malaysia. In Road Infrastructures in Tropical Forests. Rome: Food and Agriculture Organisation.

MacDonald, L. H., Sampson, R. W., and Anderson, D. M. (2001). Runoff and road erosion at the plot and road segment scales, St John, US Virgin Islands. Earth Surface Processes and Landforms, 26: 251-272.

Madej, MA. (2001). Erosion and sediment delivery following removal of forest roads. Earth Surface Processes and Landforms, 26: 175-190.

Malmer, A. and Grip, H. (1994). Converting tropical rain-forest to forest plantation in Sabah, Malaysia. 2. Effects on nutrient dynamics and net losses in streamwater. Hydrological Processes, 8: 195-209.

Mannan, S. and Awang, Y. (1997). Sustainable forest management in Sabah. Presented at the Seminar on Sustainable Forest Management, 22nd November 1997, Kota Kinabalu, Sabah, Malaysia.

Martin-Smith K. (1998). Biodiversity patterns of tropical freshwater fish following selective timber extraction: a case study from Sabah, Malaysia. Italian Journal of Zoology (Suppl. S), 65: 363-368.

Mohamed, M. (1987). Water quality studies and water quality problems in Sabah. 41-54. In Environmental Conservation in Sabah: Issues and Strategies, ed. S. Sani. Kota Kinabalu: Institute of Development Studies.

Morgan, R. P. C. (1976). Role of climate in the denudation system: a case study from West Malaysia. 317-343. In Geomorphology and Climate. E. Derbyshire (ed). London: Wiley.

MTCC. (2001). Malaysian Criteria, Indicators, Activities and Standards of Performance for Forest Management Certification (MC\&I). Kuala Lumpur: Malaysian Timber Certification Council.

Nussbaum, R., Jennings, S., and Garforth, M. (2002). Assessing forest certification schemes: a practical guide. Oxford: Proforest.

Nydegger, E. (1998). Skyline Yarding Systems for Low-impact Harvesting in Tropical Natural Forests. Sandakan: Sabah Forestry Department.

Transport Research Centre. (1993). A guide to the structural design of bitumensurfaced roads in tropical and sub-tropical countries. Overseas Research Note 31. Crowthorne: Transport Research Centre.

Pereira, H. C. (1973). Land use and water resources in temperate and tropical climates. Cambridge: Cambridge University Press.

Pinard, M. A., Putz, F. E., Tay, J. and Sullivan, T. E. (1995). Creating timber harvest guidelines for a reduced-impact logging project in Malaysia. Journal of Forestry, 93: 41-45.

Pinard, M. A., Barker, M. G., and Tay, J. (2000). Soil disturbance and post-logging forest recovery on bulldozer paths in Sabah, Malaysia. Forest Ecology and Management, 130, 213-225.

Pinard, M. A., and Putz, F. E. (1996). Retaining forest biomass by reducing logging damage. Biotropica, 28: 278-295.

Putz, F. E. (1994). Working towards a sustainable forest. Asian Timber, 9: $28-32$.

Putz, F. E., Redford, K. H., Robinson, J. G., Fimbel, R., and Blate, G. M. (2000). Biodiversity Conservation in the Context of Tropical Forest Management. Biodiversity series -impact studies, Paper No. 75. Washington: World Bank.

Roberts, J., Cabral, O. M. R., Fish, G., Molion, L. C. B., Moore, C. J., and Shuttleworth, W. J. (1993). Transpiration from an Amazonian rain-forest calculated from stomatal conductance measurements. Agricultural and Forest Meteorology, 65: 175-196.

Sabah Forestry Department. (1989). Forestry in Sabah. Sandakan: Sabah Forestry Department.

Sabah Forestry Department. (1997). SFM-Committee Work Plan. MalaysianGerman Sustainable Forest Management Project. Sandakan: Sabah Forestry Department.

Sabah Forestry Department. (1998a) Final Harvesting Plan: Compartment 43, Deramakot FR, FMU 19, Sandakan district. Sandakan: Sabah Forestry Department.

Sabah Forestry Department. (1998b). RIL Operation Guidebook Specifically for Tracked Skidder Use. Sandakan: Sabah Forestry Department.

SCS. (2002). Forest Management Certification: Evaluation on the Forest Concession Area of Perak Integrated Timber Complex. SCS-FM/COC-00046N. Oakland: Scientific Certification Systems.

SGS. (1997). Certificate of Forest Management. CFM-97/001. Kuala Lumpur: SGS (Malaysia) Sdn. Bhd.

SGS. (2002). Selangor FMU Re-assessment Report. Final Report, 3 June 2002. Kuala Lumpur: SGS (Malaysia) Sdn. Bhd. 
Sheffield, A. T., Healy, T. R., and McGlone, M. S. (1995). Infilling rates of steepland catchment estuary, Whangamata, New Zealand. Journal of Coastal Research, 11: 1294-1308.

Sidle, R. C., Pearce, A. J., and O'Loughlin, C. L. (1985). Hillslope stability and land use. Washington: American Geophysical Union.

Sist, P., Dykstra, D, and Fimbel, R. (1998). Reduced-Impact Logging Guidelines for Lowland and Hill Dipterocarp Forests in Indonesia. Occasional Paper No. 15. Bogor: Center for International Forestry Research.

Strahler, A. N. (1957). Quantitative analysis of watershed geomorphology, Transactions of the American Geophysical Union, 28: 913-920.

Swanson, F. J., and Dyrness, C. T. (1975). Impact of clear-cutting and road construction on soil erosion by landslides in the Western Cascade Range, Oregon. Geology, 3: 393-396.

Tay, J. (1999). Economic assessment of reduced impact logging in Sabah. Unpublished PhD thesis, University of Wales, Bangor, UK.

Thang, H. C. (1987). Forest management-systems for tropical high forest, with special reference to Peninsular Malaysia. Forest Ecology and Management, 21: $3-20$

Thang, H. C. (1996). Formulation and implementation of criteria and indicators for sustainable forest management in Malaysia. Paper presented at the Workshop on Forest Management Certification, Forest Research Institute Malaysia, Kuala Lumpur. 67pp.

Thang, H. C. (2002). Development and application of criteria and indicators for sustainable forest management, including forest management certification and products labeling in Malaysia - a case study. Paper presented at the Workshop on the Development of Brunei Darussalam Criteria and Indicators for Sustainable Forest Management, Bandar Seri Begawan, Brunei Darunssalam, 25-28 March 2002.

Thang, H. C. (2003). Malaysia's experience in applying criteria and indicators for sustainable forest management, including forest management certification. Paper presented at the International Conference on Criteria and Indicators for Sustainable Forest Management - The Contribution of Criteria and Indicators to Sustainable Forest Management: The Way Forward. 3-7 February 2003, Guatemala City, Guatemala.

Trewin, R., Menz, K., and Grist, P. (1998). Estimates of local and economywide costs and benefits of land uses in the Indonesian uplands through linked biological and economic models. ACIAR Indonesian Research Project Working Paper 98.01, Adelaide: University of Adelaide.

van Dam, O. (2001). Forest Filled with Gaps: Effects of Gap Size on Water and Nutrient Cycling in Tropical Rain Forest, Unpublished PhD thesis. Utrecht: Utrecht University.

van der Plas, M. C. and Bruijnzeel, L. A. (1993). Impact of mechanized selective logging of rainforest on topsoil infiltrability in the Upper Segama area, Sabah, Malaysia. In Hydrology of Warm Humid Regions. pp. 203-211, IAHS publication 216. Paris: IAHS.

Walsh, R. P. D. (1996). Drainage density and network evolution in the humid tropics: evidence from the Seychelles and the Windward Islands. Z. fur Geom. N.F. Suppl. Bd 103: 1-23.

Walsh, R. P. D., and Bidin, K. (1995). Channel head erosion in primary and logged forest in Sabah. In Abstracts of the International Association of Geomorphologists, South East Asia Conference, Singapore, 18-23 June 1995, 79 .

Wenger, S. (1999). A Review of the Scientific Literature on Riparian Buffer Width, Extent and Vegetation. Office of Public Service and Outreach, Institute of Ecology. Athens: University of Georgia.

Wyatt-Smith, J., Panton, W. P., and Mitchell, B. A. (1964). Manual of Malayan silviculture for inland forest. Malayan Forest Record No. 23. Kuala Lumpur.

Yusop, Z. (1996). Nutrient cycling in secondary rainforest catchments of Peninsular Malaysia. Unpublished PhD thesis, Manchester: University of Manchester. 